\title{
Sobrevivência em Campo de Phytophthora infestans em Hastes de Batata no Paraná, Brasil
}

\author{
Nilceu R. X. de Nazareno ${ }^{1}$, Norma Boschetto ${ }^{2} \&$ Josnei A. S. Pinto ${ }^{3}$ \\ ${ }^{1}$ Instituto Agronômico do Paraná - IAPAR, Pólo Regional de Pesquisa de Curitiba, Cx. Postal 2031, CEP 80011-970, \\ Curitiba, PR, e-mail: nilceu@iapar.br; ${ }^{2}$ Acadêmico Agronomia, UFPR, bolsista do PIBIC - CNPq/IAPAR; ${ }^{3}$ Acadêmico de \\ Agronomia, UFPR
}

(Aceito para publicação em 11/05/2004)

Autor para correspondência: Nilceu R.X. de Nazareno

\begin{abstract}
Survival of Phytophthora infestans on potato haulms under field conditions in the state of Paraná, Brazil

Potato (Solanum tuberosum) late blight caused by Phytophthora infestans is one of the most devastating foliar fungal diseases of the crop, and it is largely responsible for intensive fungicide spraying programs in southern region of Brazil. The pathogen is considered an "ecologically" obligate parasite in the

northern hemisphere for its inability to survive in the absence of living plant tissue. This experiment was designed to evaluate how long a late blight lesion would remain active as a source of inoculum in Curitiba. Under the experimental conditions tested, the potato residues did not constitute a source of survival for $P$. infestans as an inoculum source for the subsequent potato crop in the southern region of the State of Paraná, Brazil.
\end{abstract}

A Requeima da batata (Solanum tuberosum L.) causada pelo fungo Phytophthora infestans (Mont.) de Bary é a doença foliar potencialmente mais devastadora na região Sul do Brasil. A não ser na forma de oosporos, P. infestans é considerado um parasita "ecologicamente" obrigatório, pois não sobrevive na resteva de batata infestada. Esta é uma premissa do hemisfério Norte. O objetivo deste trabalho foi o de verificar a capacidade de sobrevivência de $P$. infestans no tempo, através da produção de esporângios em lesões de hastes de batata, expostas em condições de campo, na região metropolitana de Curitiba, durante os meses de outono de 2000. O experimento foi instalado no campo em 04/05/2000 na Est. Exp. do Canguiri, região metropolitana de Curitiba. De um campo de multiplicação de batata, cv. Bintje, foram coletadas hastes ainda verdes com lesões de requeima. Com uma escala milimetrada estimou-se a área de cada lesão da doença. Colocaram-se dentro de envelopes de tela de nylon (malha de 1 por $1 \mathrm{~mm}$ ) grampeados, dois pedaços de hastes com lesões de requeima com área conhecida (N.R.X Nazareno et al. Plant Disease 76:560-563, 1991). Cada envelope consistiu de uma unidade experimental. Em delineamento inteiramente casualisado e com seis repetições, os envelopes foram levados para o campo, onde a parcela compreendia um par de envelope, sendo um enterrado e o outro deixado na superfície do solo. Em períodos de 15 dias, seis repetições de amostras eram coletadas, levadas ao laboratório para lavagem em água destilada esterilizada, e colocadas em câmara úmida, no escuro e a $19^{\circ} \mathrm{C}$ por cinco dias para esporulação. Passado o período, as amostras de cada envelope eram lavadas em 50 $\mathrm{ml}$ de água destilada esterilizada com o auxílio de agitador tipo vortex, para desalojamento de esporângios. Com o auxílio de um hemacitômetro, estimava-se o número de esporângios/ ml e em seguida convertia-se para número de esporângios/ $\mathrm{mm}^{2}$ de lesão. Verificou-se que, inicialmente, as lesões de $P$. infestans estavam ativas, produzindo em média, 40 esporângios $/ \mathrm{mm}^{2}$, indicando que o patógeno estava vivo e que as hastes ainda estavam fornecendo nutrientes para a produção de inóculo. A partir da primeira amostragem, após 15 dias de exposição dos tecidos no campo, a produção de esporângios foi reduzida a zero. Tanto para hastes mantidas na superfície do solo, sujeitas à dessecação pelas condições ambientais e esterilização pela luz direta do Sol, como para as mantidas abaixo da superfície do solo, protegidas do ambiente externo, mas expostas à umidade e ação de microorganismos, $P$. infestans não teve condições de sobreviver. Estas informações confirmam aquelas de outros países (W.R. Stevenson, 2001, Compendium of Potato Diseases, APS Press), onde se postula que o patógeno não consegue sobreviver na ausência de tecido vivo do hospedeiro. As informações observadas nas condições deste experimento permitem afirmar que os restos culturais da batata em nada contribuem para sobrevivência do agente causador da requeima. A presença da doença em todas as safras indica que existem outras formas de sobrevivência do patógeno entre safras, tais como, plantas voluntárias nas lavouras de outras espécies e em amontoados de tubérculos descartados nas bordas de lavouras e estradas.

\section{AGRADECIMENTOS}

Ressaltam-se o apoio de campo do Técnico Agropecuário do Iapar, Jocemar Ferreira de Campos e a liberação da bolsa de iniciação científica do PIBIC/CNPq para a acadêmica Norma Boschetto. 